Article

\title{
Institutional Ownership and Value Relevance of Corporate Social Responsibility Disclosure: Empirical Evidence from China
}

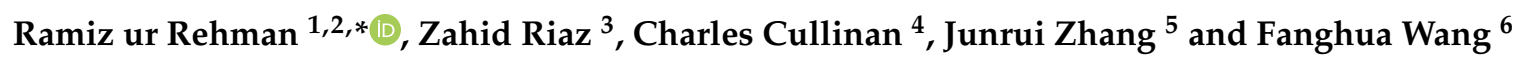 \\ 1 School of Management, Xi'an Polytechnic University, Xi'an 710048, China \\ 2 Lahore Business School, University of Lahore, Lahore 54100, Pakistan \\ 3 Faculty of Business Administration, Lahore School of Economics, Lahore 53200, Pakistan; \\ zahidriaz@lahoreschool.edu.pk \\ 4 Department of Accounting, Bryant University, Smithfield, RI 02828, USA; cullinan@bryant.edu \\ 5 Department, School of Management, Jiaotong University, Xi'an 710049, China; zhangjr@mail.xjtu.edu.cn \\ 6 College of Film and Television, Hebei University of Science and Technology, Shijiazhuang 050018, China; \\ wangfh@hebust.edu.cn \\ * Correspondence: ramiz_rehman@xpu.edu.cn
}

Received: 15 February 2020; Accepted: 11 March 2020; Published: 16 March 2020

\begin{abstract}
We examine the relationship between corporate social responsibility (CSR) disclosure and firm value in China. Using a sample of listed companies on the Shanghai Stock Exchange from 2008 to 2012, we find that market value of a firm is higher when a company makes a lower level of CSR disclosure. Other things being equal, this relationship becomes positive when the CSR disclosure is moderated with the institutional ownership. With regard to the CSR disclosure, we found consistent results with respect to the little evidence that the amount of CSR disclosure is significantly associated with market value among those companies who chose to provide CSR disclosures. Taken together, these results indicate that the decision to disclose or not to disclose CSR information is value relevant to the level of institutional investors. These findings are important as they have made an attempt to resolve the earlier contradictory findings with respect to the relationship between market value and CSR disclosure. Furthermore, it has highlighted the value relevance of CSR disclosure regarding the type of shareholders/institutional investors.
\end{abstract}

Keywords: disclosure; corporate social responsibility; firm value; institutional investors; China

\section{Introduction}

A firm may disclose discretionary information to reduce the firm's cost of capital (Cormier et al. (2011) [1]; Dhaliwal et al. [2]) and/or increase firm value (Margolis et al. [3]; Cho et al. (2013) [4]; De Klerk et al. (2015) [5]). The American Institute of Certified Public Accountants (1994, Chapter 4) [6] asserts that "increased informative disclosure benefits users by reducing the likelihood that they will misallocate their capital". One area of discretionary disclosure is related to information on a company's corporate social responsibility (CSR). With respect to CSR disclosure, Reverte (2012) [7] notes that "CSR reporting is a part of a firm's communication tools in order to decrease information asymmetries between managers and investors". (There is rich literature on the relationship between CSR activities and firm value (Wang et al. (2017) [8]). Our research focuses on the CSR reporting and firm value.)

CSR notions were first widely discussed in China when Western multinational companies faced 'anti-sweatshop' campaigns which opposed supply chain conditions in some developing countries, including China (Pun 2003) [9]. Zhou (2006) [10] notes that CSR practices began in China during the mid-1990s. CSR disclosure by Chinese firms is still a relatively recent innovation. In 2008, the Shanghai 
Stock Exchange and China's State-owned Assets Supervision and Administration Commission (SASAC, 2011) [11] began to encourage CSR information disclosure. The SASAC $(2011,18)$ [11] indicates that state-owned "[e]nterprises... should establish an information releasing mechanism, providing update[d] and regular information about CSR performance and sustainable development, plans and measures in carrying out CSR".

China is no more an exception than other developing economies regarding the recent increase in CSR disclosure. As per the recent CSR survey of KPMG, there has been a tremendous surge in CSR disclosure in the Latin Americas followed by the Asia-Pacific, Europe and Middle East and Africa regions (KPMG, 2017) [12]. This increase in CSR disclosure has intensified the interests among researchers to examine the relationship between CSR disclosure and firm value.

The studies have been conducted in both developed and developing countries, which have found a positive relationship between CSR disclosure and market value of the firm (Cochran and Wood 1984 [13]; Orlitzky, Schmidt, and Rynes 2003 [14]; Alloche and Laroche 2005 [15]; De Bakker, Groenewegen, and den Hond 2005 [16]; Wu 2006 [17]; Nakao et al., 2007 [18]; Clarkson et al., 2011 [19]; Guenster et al., 2011 [20]) [13-20]. Simultaneously, other studies have found negative association between CSR disclosure and firm value (Wood and Jones 1995 [21]; Paine 2002 [22]; Iwata and Okada 2011 [23]; Barnett and Salomon, 2012 [24]) [21-24]. Furthermore, China has a unique culture and institutional environment (Chen, Hung, \& Wang, 2018) [25], and a business culture that engenders limited engagement between management and outside stakeholders. De Villiers and van Staden (2015) [5], de Klerk and de Villiers (2012) [26], and Gray et al. (2001) [27] argue that institutional and cultural difference among countries can also influence the link between CSR disclosure and firm performance. These conflicting perspectives and inconsistent findings underline important research gaps (Isaksson and Woodside 2016) [28].

In order to address the aforementioned gaps, this paper considers the potential outcomes of CSR disclosure practices of the Chinese firms. In a recent multilevel review of literature, Jamali and Karam (2018) [29] have argued that CSR in the developing economies is locally embedded and governed by formal and informal actors. These differentiating factors give rise to the CSR of developing economies as a distinctive stream of management literature (Jamali and Karam, 2018) [29]; Basu and Palazzo, 2008 [30]. Consequently, we selected China as a relevant context to investigate the link between CSR disclosure and firm value. Furthermore, the Chinese context can enable us to discern the roles of formal and informal governance factors regarding CSR disclosure.

We focused on Chinese companies for other reasons as well. For instance, Wang and Chen [8] argue that the presence of foreign institutional investors can be a key driver behind CSR disclosure as they may have greater interest in CSR and more power to affect disclosure than smaller local shareholders. Second, most studies considering the outcomes of CSR disclosures have focused on developed economies where the notion of CSR has been greatly refined to represent the current mainstream literature (Jamali and Karam 2018) [29]; Williams and Pei 1999 [31]; Smith, Adhikari, and Tondkar 2005 [32]; Gray and Bebbington 2007 [33]). Fewer studies have been conducted on CSR disclosures in developing nations (Haniffa and Cook 2005 [34]; Islam and Deegan 2008 [35]) [34,35], such as China where there can be distinctive political structure, social norms, and religious environment, thereby representing both formal and informal factors of governance (Baron and Tang 2009 [36]; Du et al. 2016 [37]) [36,37]. For example, Marquis et al. (2013) [38] argue that the objective of issuing CSR reports can include gaining goodwill with the government, which has a more powerful economic role than in many developed countries. Singh (2017) [39] notes that "Chinese firms are proactively reaching out to engage government, customers, investors, creditors and suppliers in multifaceted initiatives to bolster legal compliance, create better brand equity, strengthen financial oversight, and ensure sound manufacturing principles" [39]. Using a sample of the Chinese listed firms from 2008 to 2012, we found that market value of the firm is lower when a company discloses CSR information than when a company does make such disclosures. Notwithstanding, this relationship becomes opposite when more of the shares of the firms are owned by institutional investors. Taken together, these results 
indicate that the decision to disclose or not to disclose CSR information is value relevant to investors, especially institutional investors.

In the past, some studies have found a positive relationship between CSR disclosure and market value of the firm (Cochran and Wood 1984 [13]; De Bakker, Groenewegen, and den Hond 2005 [16]). However, other studies found a negative association between CSR disclosure and firm value (Wood and Jones 1995 [21]; Paine 2002 [22]; Barnett and Salomon, 2012 [24]; Al-Dah 2018 [40]). Our findings have addressed these conflicting perspectives and inconsistent findings in the context of a developing economy (Isaksson and Woodside [28], 2016, Jamali and Karam, 2018 [29]). Very recently, it is argued that the value relevance of CSR can be better understood through the juxtaposition of theory and context (Jamali and Karam, 2018 [29]; Windsor, 2019 [41]). It is due to the fact that country specific conditions are currently shaping CSR. Jamali and Karam (2018) [29] and Windsor (2019) [41] have argued that CSR in the context of a developing economy should be considered as a distinctive stream. As a matter of fact, limited efforts have been made to comprehend the CSR in developing economies and CSR practices have been less formal in these countries (Matten and Moon, 2008 [42]; Jamali and Mirshak, 2007 [43]; Sajjad and Eweje, 2014 [44]; Jamali and Karam, 2018 [29]). Consequently, we took the debate of context-dependence CSR forward and our findings confirm that the value relevance of CSR is contingent upon the level of institutional shareholding in China.

Our research contributes to the literature in the following manner. First, we extend the literature on the CSR disclosure/firm value relationship (de Villiers and Marques 2016) [45], which has produced conflicting results (De Klerk, M., de Villiers, C., and van Staden, C. 2015 [5]; de Klerk and de Villiers, 2012 [27]; Murray et al. 2006 [46]; Schadewitz and Niskala, 2010 [47]) across both developed and developing economies. Second, we demonstrate whether the CSR disclosure/firm value relationship can be influenced by any other extraneous factors, such as the extent of institutional shareholding. Our findings confirm the notion that Chinese firms are willing to incur the marginal cost of increasing disclosure if there is substantial economic interaction between the institutional investors and firms. It is imperative to mention that in recent times institutional shareholding has become more prevalent in China (Jiang and Kim 2015) [48], and institutional investors may have more concern about CSR disclosures than other types of investors (Wang and Chen 2017) [8].

\section{Theory and Hypotheses}

\subsection{CSR Disclosure and Financial Markets}

Agency theory suggests that the proper functioning of capital markets can be impaired if there is information asymmetry due to inadequate disclosure (Beaver, 1998 [49]; Diamond \& Verrecchia, 1991 [50]). Monitoring by the shareholders (the principals in agency theory) can be improved through frequent and consistent disclosure of information, and disclosures can enable shareholders to manage conflicts of interest in an agency relationship (Gilson \& Kraakman, 1984 [51]; Merton, 1987 [52]; Thévenoz \& Bahar, 2007:19 [53]) [51-53]. An effective monitoring through disclosure can decrease the firm's cost of capital and enable shareholders to more effectively assess risk and make investment decisions (Diamond \& Verrecchia, 1991 [50], (Healy and Pelepu 2001) [54]. More disclosure can also reduce managerial opportunism and market failures (Cooper \& Keim, 1983 [55]; Eisenhardt, $1989[56])[55,56]$.

There has been an increase in the level of CSR disclosure for many companies in present times, which often results from regulatory interventions (Jain, Aguilera, \& Jamali, 2017 [57]; Qian \& Schaltegger, 2017 [58]; Shabana, Buchholtz, \& Carroll, 2017 [59]) [57-59]. The empirical literature provides mixed results with respect to the impact of the disclosure of CSR information on the share prices. For instance, Lorraine et al. (2004) [60] suggest companies that disclose negative environmental and social information experience decline in share prices, but the share price does not react to positive CSR information. However, Curran and Moran (2007) [61] found no relationship between deletion or inclusion of a firm on the FTSE4Good UK Index and financial returns. In the context of emerging 
economies, research also finds conflicting results regarding the value relevance of CSR disclosure and presents a need for further research (Chen et al., 2018 [25]; de Klerk et al., 2015 [5]; Jain et al., 2017 [57]; Wang, Dou, \& Jia, 2016 [62]).

A recent literature review of CSR disclosure has found that the concerns of key local stakeholders, including regulators, shareholders, institutional investors, creditors, environmentalists, and the media, are considered very significant regarding the level of CSR information disclosure in developed economies (Ali, Frynas, \& Mahmood, 2017) [63]. However, the CSR disclosure in developing economies is related to non-local actors, such as international buyers, institutional/foreign investors, international media, and supra-national regulatory bodies (Ali et al., 2017) [63]. In the case of China, the notion of CSR disclosure became popular in 2008 and research has produced mixed results on the antecedents and outcomes of such disclosure in China (Chen et al., 2018 [25]; Cheng, Lin, \& Wong, 2016 [64]). Focusing on antecedents, $\mathrm{Li}$, Luo, Wang and $\mathrm{Wu}$ (2013) [65] found that companies with stronger financial performance disclose more CSR information, and this relationship was stronger for non-state-owned enterprises. With regard to outcomes of CSR disclosure, Ye and Zhang (2011) [66] found a U-shaped relationship between CSR disclosure and costs of debt financing in China. In this backdrop, we examine the value relevance of CSR information in China and explore how the level of institutional shareholding can impact the value relevance of CSR disclosure.

\subsection{Value Relevance of CSR Disclosure}

Due to a recent surge in CSR disclosure, researchers have started to ascertain the value relevance of CSR disclosure by examining the direct link between market value of a firm and CSR disclosure. Some studies have examined the relationship between CSR disclosure and financial performance/firm value have found a positive link (for details see, e.g., Cochran and Wood, 1984 [13]; Orlitzky, Schmidt, and Rynes 2003; Alloche and Laroche 2005 [14]; De Bakker, Groenewegen, and den Hond 2005 [16]; Wu 2006; Nakao et al., 2007 [17]; Clarkson et al., 2011 [19]; Guenster et al., 2011 [20]). Although, other studies do not find a positive relationship (for details see, e.g., Wood and Jones 1995 [21]; Paine 2002 [22]; Iwata and Okada 2011 [23]; Barnett and Salomon, 2012 [24]).

Even the recent studies have found inconsistent results regarding the value relevance of CSR disclosure (for details see Cho et al. 2015 [67]; Cahan et al. 2016 [68]; de Villiers and Marques 2016 [45]; Plumlee et al. 2015 [69]). Furthermore, these studies argue that the relationship between CSR disclosure and firm value can be contingent on an institutional context. For instance, de Villiers and Marques (2016) [45] found that the CSR disclosure and market value relationship is stronger in developed economies due to robust market and non-market institutions. These countries have usually strong democratic governance systems, a market-oriented regulatory regime, and more freedom of expression. They posit that this stronger relationship is related to the greater ability of investors to voice their concerns, thereby leading to investor protection through increased disclosure and transparency. Conversely, Cahan et al. (2016) [68] found that unanticipated CSR disclosure is positively related with the firm value in the context of weaker national institutions. Furthermore, Islam et al. (2008) [35] has found that the domestic Chinese companies often disclose anti-bribery information in their CSR reports to generate their social capital. As China has introduced several initiatives for the regulation of CSR in 2008, consequently, it is very relevant to investigate the value relevance of CSR disclosure in the context of China.

Generally, the empirical evidence provides greater support that companies of better financial performance and cash flows make higher levels of CSR disclosure. The value relevance of CSR disclosure demonstrates that better performing firms are willing to commit more resources for CSR activities and their disclosure (Peloza 2009 [70], p. 1518). According to the theory of slack resources, the other strand of literature, however, argues that firms with better financial performance preferred to spend these resources for CSR activities, thereby confounding the link between CSR and firm performance (Waddock and Graves, 1997 [71]). Besides, it has been argued that firms in financial distress may have little intention to invest in CSR and therefore denote better performance as the 
antecedent of more CSR (McGuire et al., 1990 [72]; Godfrey et al., 2009 [73]). This argument was examined in the context of a developing economy—Ghana—and Julian and Ofori-dankwa (2013) [74] found that better performing firms were allocating less resources for CSR activities. Similarly, a meta-analysis study of Wang et al. (2016) [62] did not find any support in the favor of slack resources theory of CSR, thereby rejecting the notion of reverse causality between the financial performance and CSR performance of the firm. Moreover, recent studies of value relevance of CSR disclosure mostly found that greater disclosure is associated with higher market value of the firms (for details see, Cahan et al. 2016 [68]; de Villiers and Marques 2016 [45]; Wang et al. 2016 [62]; Ali et al., 2017 [63]; Plumlee et al. 2015 [69]). In the light of the above discussion, we propose a positive, direct, and significant relationship between CSR disclosure and market value of firms.

Hypothesis 1: The disclosure of CSR is positively related with the market value of the firm.

\subsection{Institutional Shareholding and Value Relevance of CSR Disclosure}

Recent research has begun to consider the role of institutional investors in the CSR disclosure/firm value relationship (Cho et al. 2015 [67]; Cahan et al. 2016 [68]; de Villiers and Marques 2016 [45]). For example, de Villiers and Marques (2016) [45] found that the CSR disclosure/market value relationship is stronger in developed economies, which they suggest it is related to the greater ability of investors to voice their concerns, thereby leading to investor protection through increased disclosure and transparency. Due to their larger shareholding and influence, it has been argued that institutional investors can have a greater voice in demanding more CSR disclosure (Solomon and Solomon, 2006 [75]; Solomon, Solomon and Norton, 2002 [76]).

Institutional investors may be one of the factors that can enhance the CSR disclosure and firm value relationship. In the context of the UK, disclosure about environmental information (a subset of CSR disclosure) is considered relevant by both institutional and individual shareholders (Solomon and Solomon, 2006 [75] (de Villiers and van Staden, 2010 [77]). Some research suggests that CSR disclosure can reveal the current strategies and preparedness of firms and therefore assist institutional investors in making better projections of future cash flows and earnings (de Klerk, de Villiers, van Staden, 2015) [5]. Likewise, more CSR disclosure can appeal to institutional investors who typically have longer term investment horizons (Dhaliwal et al., 2011 [2]; de Klerk, de Villiers, van Staden, 2015 [5]).

In early 2008, the China Security Regulatory Commission (CSRC) and the State General Administration of Foreign Exchange (SAFE) began to permit foreign institutional investors access to the Chinese equity markets. Institutional investors have increased their holdings of Chinese shares and these investors are the main driving force of CSR disclosures in China because individual and Chinese retail investors have little knowledge about CSR (Wang and Chen 2017 [8]); Jiang and Kim 2015 [48], Lin, 2010 [78]. In this regard, the empirical evidence suggests that institutional investors seem to be more vigilant towards the CSR-related actions of Chinese firms and therefore they value CSR disclosure (Firth et al. 2016 [79]; Peng et al. 2013 [80]; Wang et al., 2017 [8]).

As mentioned earlier, better disclosure of CSR activities can assist firms to address the issue of information asymmetry and enable them to better assess risk and value equities (Cho et al., 2013 [4]; de Klerk, de Villiers, van Staden, 2015 [5]). Institutional investors may have the knowledge and interest in CSR disclosure and the long-term perspective to see the value in CSR activities. We therefore propose that institutional investors can moderate the relationship between CSR disclosure and firm value-the CSR disclosure/firm value relationship may be stronger when institutional investors hold more of a firm's shares. Our second hypothesis is therefore proposed in the following manner.

Hypothesis 2: Institutional shareholding positively moderates the relationship between CSR disclosure and firm value. 


\section{Research Design}

\subsection{Sample}

The initial sample consisted of all Chinese firms listed on the Shanghai Stock Exchange from the period 2008 to 2012. Our sample starts in 2008 when the State-owned Assets Supervision and Administration Commission and the Shanghai Stock Exchange began to encourage companies to disclose CSR information. The financial data of the sample companies A-share were collected from China Stock Market and Accounting Research (CSMAR). Due to different reporting requirements, we have excluded firms that belong to the financial industry (Haniffa and Cook, 2005 [34]; Qi et al., 2013 [65].

Data were taken from the CSMAR database. The details of the sampling process are summarized in Table 1. The sample was divided into two categories: firms that disclose CSR (DCSR firm-years) and those that did not disclose CSR information (NDCSR firm-years). Panel A indicates that the total percentage of CSR-disclosing firm for all years is $18.13 \%(1835 / 10,118)$. This percentage is lower than comparable percentages in developed countries, such as the $41.1 \%$ disclosure rate among US firms found by Holder-Webb et al. (2009) [81], and the 53\% disclosure rate among the largest 100 companies of 22 countries in 2008 reported by KPMG (2011) [12]. Since 2008, Chinese stock exchanges and the State-owned Assets Supervision and Administration Commission have encouraged disclosure of CSR performance for Chinese firms. The number of Chinese-listed companies reporting CSR information increased from 168 in 2008 to 535 in 2012. The different relative power of institutional shareholders in China, the distinctive cultural/political environment in China, and explicit encouraging of CSR disclosure in China, make the Chinese context an appropriate context in which the impact of voluntary CSR disclosure on firm value can be examined. This increasing trend of CSR can be observed in Table 1 over the years from 2008 to 2012. The percentage of companies disclosing CSR information increased from $10.42 \%$ in 2008 to $22.35 \%$ in 2012 . The distribution of the sample as per the industry category is presented in Panel B of Table 2.

Table 1. Panel A: Year-wise sample distribution.

\begin{tabular}{cccc}
\hline Year & DCSR & NDCSR & Total \\
\hline 2008 & 168 & 1443 & 1611 \\
2009 & 176 & 1572 & 1748 \\
2010 & 439 & 1642 & 2081 \\
2011 & 517 & 1768 & 2285 \\
2012 & 535 & 1858 & 2393 \\
\hline Total & 1835 & 8283 & 10,118 \\
\hline
\end{tabular}

\subsection{Dependent Variable and Empirical Model}

To examine the potential relationship between CSR disclosure and market value of the firm, this study follows the Ohlson valuation theory model (1995) [82]. In his contribution, Ohlson asserts that the expected earnings of a firm can be predicted though accounting earnings and the value of relevant information not yet captured by accounting measures.

Model 1

$$
\begin{gathered}
\frac{M V_{i, t+1}}{T A_{i, t-1}}=\alpha+\beta_{0} \frac{B V_{i, t-1}}{T A_{i, t-1}}+\beta_{1} \frac{N I_{i, t}}{T A_{i, t-1}}+\beta_{2} \operatorname{DCSR}_{i, t}+\beta_{3} S O E_{i, t}+\beta_{4} \operatorname{InstSH}_{i, t} \\
\quad+\beta_{5} S O E X \operatorname{DCSR}_{i, t}+\beta_{6} \text { InstSHX XCSR } \text { In }_{i, t}+\sum_{j}^{n} \beta_{j} C_{i, t}+\mu_{i}+\epsilon_{i}
\end{gathered}
$$

where $M V_{i, t+1}$ is a market value of ith firm at $\mathrm{t}+1$ time period, $\frac{B V_{i, t-1}}{T A_{i, t-1}}$ is the ratio of book value to total asset of ith firm at $\mathrm{t}-1$ time period, $\frac{N I_{i, t}}{T A_{i, t-1}}$ is the ratio of firm net income at time period to total assets at $\mathrm{t}-1$, and $D C S R_{i, t}$ is a dummy variable which measures whether the firm discloses CSR information. The 
DCSR variable takes the value of 1 if the firm discloses CSR information, and 0 otherwise. The DCSR variable is used to test Hypothesis 1, which posits a positive relationship between CSR information disclosure and firm market value. InstSH $\mathrm{H}_{i, t}$ is the percentage of shares held by institutional shareholders. We interact the InstSH $H_{i, t}$ variable with the DCSR variable to test Hypothesis 2, which suggests that the CSR disclosure/firm value relationship is stronger when institutional shareholders own more of the firm's shares. SOE (State Owned Enterprise) is a dummy variable with a value of 1 if the firm is a state-owned enterprise, and 0 if the firm is not state-owned. SOE is included in this study as a control variable. Beginning in 2008, SOEs were encouraged by the Chinese State-owned Assets Supervision and Administration Commission (SASAC) to follow good CSR practices and to report on their CSR activities (SASAC, 2011) [11].

Table 2. Panel B: Sample distribution.

\begin{tabular}{ccccc}
\hline Industry Name & DCSR & NDCSR & Total & \% of DCSR \\
\hline Agriculture, forestry, animal husbandry and fishery & 34 & 178 & 212 & 16 \\
Coal, oil and gas, mining services & 77 & 130 & 207 & 37 \\
Cement, textiles, sugar, food, beverages, cooking oil & 360 & 2098 & 2458 & 15 \\
Chemical raw materials and chemical products & 111 & 592 & 703 & 16 \\
Electronic components & 55 & 340 & 395 & 14 \\
Non-metallic minerals & 55 & 266 & 321 & 17 \\
Black metal smelting and rolling processing & 59 & 105 & 164 & 36 \\
Non-ferrous metal smelting and rolling processing & 81 & 123 & 204 & 40 \\
Petrochemical and other industrial specialized equipment & 82 & 402 & 484 & 17 \\
Transportation equipment & 71 & 364 & 435 & 16 \\
Electrical machinery and equipment & 81 & 378 & 459 & 18 \\
Pharmaceutical & 90 & 426 & 516 & 17 \\
Construction & 83 & 261 & 344 & 24 \\
Transportation industry & 39 & 159 & 198 & 20 \\
Power, steam, hot water production and supply industry & 100 & 244 & 344 & 29 \\
Computer application services & 123 & 665 & 788 & 16 \\
Real estate & 88 & 467 & 555 & 16 \\
Tobacco and household goods, energy, materials & 123 & 442 & 565 & 22 \\
Scientific research, health care, tourism, social services & 38 & 284 & 322 & 12 \\
Information dissemination, publication communication & 17 & 88 & 105 & 16 \\
Comprehensive industries & 68 & 271 & 339 & 20 \\
\hline Total & 1835 & 8283 & 10,118 & \\
\hline
\end{tabular}

We also include a variety of control variables in our firm value models. $C_{i, t}$ represents the other control variable, such as firm size, defined as the natural logarithm of total assets.

\section{Model 2}

In addition to measuring whether the company discloses CSR information or not (in Model 1), we also considered the extent of such CSR disclosures in Model 2.

$$
\begin{aligned}
& \frac{M V_{i, t+1}}{T A_{i, t-1}}=\alpha+\beta_{0} \frac{B V_{i, t-1}}{T A_{i, t-1}}+\beta_{1} \frac{N I_{i, t}}{T A_{i, t-1}}+\beta_{2} \text { CSRScore }_{i, t}+\beta_{3} S_{\text {SOE }} E_{i, t}+\beta_{4} I_{n s t S H} H_{i, t} \\
& \quad+\beta_{5} \text { SOE X CSRScore }{ }_{i, t}+\beta_{6} \text { InstSH X CSRScore }_{i, t}+\sum_{j}^{n} \beta_{j} C_{i, t}+\mu_{i}+\epsilon_{i}
\end{aligned}
$$

Firms may have differing levels of disclosures in their CSR reports. Categories of disclosures include worker safety, system construction, public relations, environmental protection, customer protection, delivery protection, staff protection, creditor protection, and shareholder protection. A CSR score was developed based on the extent of CSR disclosures. If a firm discloses one CSR item, it is coded as 1 and if the firm discloses all the possible items, the CSR score is coded as 10. As with Model 1 , we also tested this model using the log of market value as the dependent variable. 


\section{Results and Findings}

\subsection{Descriptive Statistics}

Descriptive statistics of the sample companies are presented in Table 3. The mean market value to total assets of the full sample is 2.2, with a minimum and maximum value of 0.28 and 1.40, respectively. The average (logged) firm size is 21.62, which is consistent with Qi et al., 2013 [65].

Table 3. Descriptive statistics—full sample.

\begin{tabular}{ccccc}
\hline Variable & Mean & Min & Max & Std. Dev. \\
\hline Market Value to Asset & 2.2 & 0.28 & 9.9 & 1.40 \\
BV to Asset & 0.53 & -0.53 & 0.998 & 0.26 \\
Net Income to Asset & 0.06 & -2.39 & 8.44 & 0.24 \\
Size & 21.62 & 14.10 & 27.85 & 1.26 \\
CSR Disclosure * & $19 \%$ & 0 & 1 & \\
CSR Score & 1.46 & 0 & 10 & 3.09 \\
State Owned Ent. ** & $48 \%$ & 0 & 1 & \\
Institutional Shareholding & 8.26 & 0 & 78.01 & 12.82 \\
Board Size & 8.69 & 0 & 18 & 2.35 \\
Independent Director & 3.1 & 0 & 8 & 0.86 \\
\hline
\end{tabular}

Note: ${ }^{*}$ The percentage of firms in the total sample which make CSR disclosures. ${ }^{* *}$ The percentage of firms which are state owned enterprises in the sample.

We present comparisons of means in Table 4. Most of the variables are different between the DCSR (CSR disclosing) and NDCSR (non-CSR disclosing) sub-samples. For example, the mean market value of DCSR firms is significantly greater than NDCSR firms. The mean values of net income, book value, and size of DCSR firms are also significantly higher for DCSR than for NDCSR firms. The mean values of board size and independent director are also higher for DCSR than for NDCSR firms.

Table 4. Comparison of means.

\begin{tabular}{ccccc}
\hline Variable & DCSR & NDCSR & t-Test & P-Value \\
\hline Mean & Mean & & \\
\hline MVTA & 0.59 & 0.72 & 7.48 & $0.000^{* * *}$ \\
NITA & 0.09 & 0.10 & 0.15 & 0.8732 \\
BVTA & 1.76 & 2.19 & 0.25 & 0.7977 \\
Size & 22.58 & 21.39 & -38.51 & $0.000^{* * *}$ \\
Board Size & 9.30 & 8.55 & -12.31 & $0.000^{* * *}$ \\
Independent Director & 3.40 & 3.09 & -13.62 & $0.000^{* * *}$ \\
\hline
\end{tabular}

Note: * in RMB in 100 Million. ${ }^{* * *}$ Significance at $1 \%$ level of significance.

Table 5 presents the pair-wise Pearson product-moment correlation coefficients of the variables. It includes all of the observations and the CSR disclosure measure is based on a dichotomous measure of whether the firm discloses CSR or not. Gujarati (2009) [83] and Tabachnick and Fidell (2013) [84] indicate that statistical problems which are created by collinearity and singularity can take place at a higher bivariate correlation of 0.90 and above. The correlation coefficient values show that there is no serious problem of multicollinearity because all the correlation coefficients are less than 0.90 . Variance inflation factors (VIFs) and tolerance values for each variable are also computed and shown in Table 5. The VIFs and tolerance values indicate no material concerns with multicollinearity; the VIFs are below 10 and the values of tolerance were greater than 0.10 . 
Table 5. Pairwise correlation.

\begin{tabular}{|c|c|c|c|c|c|c|c|c|c|c|c|}
\hline & Variables & 1 & 2 & 3 & 4 & 5 & 6 & 7 & 8 & Variance Inflation Factor & Tolerance \\
\hline 1 & MV to total asset & 1 & & & & & & & & & \\
\hline 2 & BV to total asset & $-0.4119^{* * *}$ & 1 & & & & & & & 1.46 & 0.685 \\
\hline 3 & NI to total Asset & $0.4000 * * *$ & $0.0754 * * *$ & 1 & & & & & & 1.18 & 0.845 \\
\hline 4 & DCSR & $-0.0886 * * *$ & $0.1029 * * *$ & $0.0684^{* * *}$ & 1 & & & & & 1.89 & 0.528 \\
\hline 5 & Board size & $-0.0839 * * *$ & $0.0991 * * *$ & 0.0091 & $0.1258^{* * *}$ & 1 & & & & 1.10 & 0.912 \\
\hline 6 & SOE & $-0.0769 * * *$ & $0.0622^{* * *}$ & $-0.1222 * * *$ & $0.1254^{* * *}$ & $0.1698^{* * *}$ & 1 & & & 1.20 & 0.831 \\
\hline 7 & InstSH & $0.1685^{* * *}$ & 0.0067 & $0.3407^{* * *}$ & $0.1272^{* * * *}$ & $0.0868^{* * *}$ & $-0.0295^{* *}$ & 1 & & 1.60 & 0.625 \\
\hline 8 & InstSH * CSR disclosure & $0.0596^{* * *}$ & 0.0176 & $0.1771 * *$ & $0.6052 * *$ & $0.1033^{* *}$ & $0.0670 * *$ & $0.4490 * *$ & 1 & 2.15 & 0.464 \\
\hline 9 & Size & $-0.3811 * *$ & $0.5461 * *$ & -0.0169 & $0.3687^{* *}$ & $0.2574^{* *}$ & $0.3476^{* *}$ & $0.1951 * *$ & $0.2550 * *$ & 2.01 & 0.497 \\
\hline
\end{tabular}

${ }^{* * *}$ Significant at $\mathrm{p}<0.01 ;{ }^{* *}$ significant at $\mathrm{p}<0.05 ;$ and ${ }^{*}$ significant at $\mathrm{p}<0.10$ 


\subsection{Regression Results: Disclosing or not Disclosing}

Table 6 presents the results of panel data regression models with random and fixed effect. In these models, the dependent variable is firm value divided by total assets. In the fixed effect model, the table shows the empirical evidence of [82]'s accounting-based valuation model, in which the coefficient of net income to total assets is 0.23 , significant at $1 \%$ level of significance with an $R^{2}$ of $21 \%$, indicating that the firm's accounting earnings predict the expected market value of that firm. The coefficient of DCSR of -0.136 is significant at $1 \%$. This result is not consistent with Hypothesis 1 (H1) and suggests that firms disclosing CSR information have lower market values. The institutional shareholding (InstSH) and its interaction with DCSR variables test $\mathrm{H} 2$. The coefficients on InstSH are significant at $1 \%$, and the coefficient on the InstSH * DCSR interaction variable is significant at $5 \%$, supporting $\mathrm{H} 2$, which posited that institutional shareholding would strengthen the CSR disclosure firm value relationship.

Table 6. Panel regression-market value to total asset-full sample.

\begin{tabular}{|c|c|c|c|}
\hline Items & Random Effect & Fixed Effect & GMM \\
\hline Constant & $\begin{array}{c}4.67 \\
\left(24.84^{* * *}\right)\end{array}$ & $\begin{array}{c}9.41 \\
\left(21.94^{* * *}\right)\end{array}$ & $\begin{array}{c}3.64 \\
(9.37 * * *)\end{array}$ \\
\hline BV/TA_1 & $\begin{array}{c}-0.078 \\
\left(-7.30^{* * *}\right)\end{array}$ & $\begin{array}{c}0.169 \\
\left(11.99^{* * *}\right)\end{array}$ & $\begin{array}{c}-0.248 \\
\left(-4.47^{* * *}\right)\end{array}$ \\
\hline NI/TA_1 & $\begin{array}{c}0.228 \\
\left(37.90^{* * *}\right)\end{array}$ & $\begin{array}{l}0.227 \\
\left(31.86^{* * *}\right)\end{array}$ & $\begin{array}{l}0.212 \\
\left(14.20^{* * *}\right)\end{array}$ \\
\hline DCSR & $\begin{array}{l}-0.0958 \\
\left(-4.49^{* * *}\right)\end{array}$ & $\begin{array}{c}-0.136 \\
\left(-5.52^{* * *}\right)\end{array}$ & $\begin{array}{c}-0.065 \\
\left(-3.34^{* * *}\right)\end{array}$ \\
\hline BS & $\begin{array}{c}-0.009 \\
\left(-2.49^{* *}\right)\end{array}$ & $\begin{array}{l}-0.002 \\
(-0.47)\end{array}$ & $\begin{array}{l}-0.0002 \\
(-0.09)\end{array}$ \\
\hline SOE & $\begin{array}{c}0.209 \\
\left(11.28^{* * *}\right)\end{array}$ & $\begin{array}{l}0.013 \\
(0.31)\end{array}$ & $\begin{array}{c}0.112 \\
\left(6.94^{* * *}\right)\end{array}$ \\
\hline InstSH & $\begin{array}{c}0.005 \\
\left(7.59^{* * *}\right)\end{array}$ & $\begin{array}{c}0.007 \\
\left(9.05^{* * *}\right)\end{array}$ & $\begin{array}{c}0.004 \\
\left(5.03^{* * *}\right)\end{array}$ \\
\hline InstSH * DCSR & $\begin{array}{c}0.003 \\
\left(3.00^{* * *}\right)\end{array}$ & $\begin{array}{c}0.002 \\
\left(2.06^{* *}\right)\end{array}$ & $\begin{array}{c}0.004 \\
\left(3.30^{* * *}\right)\end{array}$ \\
\hline Size & $\begin{array}{c}-0.154 \\
\left(-17.18^{* * *}\right)\end{array}$ & $\begin{array}{c}-0.365 \\
\left(-18.67^{* * *}\right)\end{array}$ & $\begin{array}{c}-0.112 \\
\left(-7.16^{* * *}\right)\end{array}$ \\
\hline $\begin{array}{c}\text { No. of Observations } \\
R^{2}\end{array}$ & $\begin{array}{c}6424 \\
0.3206\end{array}$ & $\begin{array}{c}6424 \\
0.2127\end{array}$ & 6288 \\
\hline Model Test statistics & 2567.57 & 265.77 & \\
\hline Prob & 0.00 & 0.00 & \\
\hline Hausman Test Chi-Sq (p-value) & & $2614.42(0.000)$ & \\
\hline Hansen -J Chi-Sq (p-value) & & & $0.070(0.7912)$ \\
\hline
\end{tabular}

Note: ${ }^{* * *}$, and ${ }^{* * *}$ are the level of significance at $10 \%, 5 \%$, and $1 \%$.

Endogeneity is well documented in research that examines the association between market value and CSR disclosure (Cavaco and Crifo, 2014 [85]). The generalized method of moments (GMM) estimator cannot only assist to address the issue of endogeneity, but it can control for the underlying heterogeneity and simultaneity issues related to the CSR disclosure/market value relationship. In comparison to the conventional effect estimates, the GMM technique allows CSR disclosure scores to be affected by the financial performance of the past years (Cavaco and Crifo, 2014, p. 3329 [85]). Furthermore, the GMM methodology facilitates the use of internal instrumental variables. The use of the GMM estimator helps to control for unobserved firm heterogeneity for examining the link between financial performance and CSR, as argued by Belu and Manescu (2013) [86]. In order to ensure the validity of instruments used by the GMM system, the Hansen's J test of over-identification can be used. Due to usage of multiple lag variables as instruments under the GMM technique, the validity of these instruments can be verified through the above-mentioned test (Hansen 1982 [87]; Cavaco and Crifo, 2014, p. 3330 [85]). 
The results of GMM, where the number of moments are more than the number of parameters, are presented in Table 6. In order to check for the over identification, the Hansen's J test of over identification restrictions has been performed as well. Table 6 indicates that the p-value is insignificant and over-identification restrictions are valid. Hence, the usage of the GMM technique is appropriate for the specification of the model.

The results in Table 6 for GMM show that the coefficient for net income as the proportion of total assets is positively related with the market value to total assets $(\beta=0.221, p<0.01)$. However, there is negative impact of total book value as the proportion of total assets on the market value to total assets $(\beta=-0.248, p<0.01)$. These results indicate that accounting measures of firms predict the market value of the firms as per Ohlson's (1995) accounting-based valuation model. For Hypothesis 1, we found firms which provide CSR disclosure have lower market value $(\beta=-0.065, p<0.01)$. With regard to Hypothesis 2, we found a positive coefficient for the interaction variables between institutional ownership and disclosure of CSR information (InstSH* DCSR) $(\beta=0.004, p<0.01)$ as shown in Table 5 for GMM. This result indicates that firms with higher levels of institutional shareholding that disclose CSR have higher market values. These findings support Hypothesis 2, which postulates that the relationship between market value of the firm and the existence of CSR disclosure is moderated by institutional shareholding. In order to examine the unique impact of the above-mentioned explanatory variables on the market value of the firm, board size and status of firms as state-owned enterprises have been controlled in this research. The board size is negatively related with the market value of the firm, whereas state-owned enterprises have higher market value of the firm than non-state owned enterprises.

\subsection{Robustness Check-Extent of CSR Disclosure}

To examine the potential relationship between CSR disclosure and firm value, we also considered the extent of disclosure, not just whether there was disclosure or not. Table 7 presents some descriptive statistics on the type of information disclosed by those firms that chose to make CSR disclosures. The most common types of disclosures in 2012 involved environmental protection, staff protection, and shareholder protection initiatives. Based on this information, we developed a CSR score variable that ranges in value from 1 to 10 based on the number of disclosure items included in the firm's CSR report.

Table 7. CSR item disclosure percentage.

\begin{tabular}{cccccc}
\hline Disclosure Items & $\mathbf{2 0 0 8}$ & $\mathbf{2 0 0 9}$ & $\mathbf{2 0 1 0}$ & $\mathbf{2 0 1 1}$ & $\mathbf{2 0 1 2}$ \\
\hline Deficiency & $3 \%$ & $4 \%$ & $5 \%$ & $5 \%$ & $5 \%$ \\
Worker Safety & $8 \%$ & $8 \%$ & $18 \%$ & $19 \%$ & $19 \%$ \\
System Construction & $5 \%$ & $5 \%$ & $6 \%$ & $10 \%$ & $7 \%$ \\
Public Relations & $10 \%$ & $10 \%$ & $20 \%$ & $21 \%$ & $21 \%$ \\
Environmental Protection & $10 \%$ & $10 \%$ & $21 \%$ & $22 \%$ & $22 \%$ \\
Customer Protection & $10 \%$ & $10 \%$ & $20 \%$ & $22 \%$ & $21 \%$ \\
Delivery Protection & $8 \%$ & $8 \%$ & $15 \%$ & $17 \%$ & $17 \%$ \\
Staff Protection & $10 \%$ & $10 \%$ & $21 \%$ & $22 \%$ & $22 \%$ \\
Creditor Protection & $8 \%$ & $7 \%$ & $13 \%$ & $14 \%$ & $14 \%$ \\
Shareholder Protection & $10 \%$ & $10 \%$ & $21 \%$ & $22 \%$ & $22 \%$ \\
CSR Score Min * & $89.5 \%$ & $89.8 \%$ & $78.9 \%$ & $77.5 \%$ & $77.7 \%$ \\
CSR Score Max * & $1.1 \%$ & $1.8 \%$ & $3.2 \%$ & $2.9 \%$ & $3.4 \%$ \\
\hline
\end{tabular}

* CSR score ranges from 1 to 10. Min CSR scores means a firm only discloses one item of CSR and achieves a CSR score of 1 . Similarly, if a firm discloses all ten items of CSR in its financial report then it can achieve a maximum CSR score of 10 .

We present the results of testing the extent of disclosure in Table 8 (MV/TA (market value to total asset) as the dependent variable). In these models, only those companies that chose to disclose at least some CSR information (1441 firm-years) are included and the DCSR variable is replaced with the CSR score. The extent of disclosure (CSR score) is marginally significant (at the 5\% level) and 
negative in the fixed effect model. The institutional shareholding interaction variable is also significant at $5 \%$. These results, taken together with those presented in Table 6, indicate that greater disclosure does not appear to have an incremental positive influence on firm value, unless firms have larger institutional shareholdings.

Table 8. Panel regression-market value to total asset—disclosed sample.

\begin{tabular}{|c|c|c|}
\hline Items & Random Effect & Fixed Effect \\
\hline Constant & $\begin{array}{c}2.02 \\
\left(7.68^{* * *}\right)\end{array}$ & $\begin{array}{c}8.23 \\
\left(7.11^{* * *}\right)\end{array}$ \\
\hline BV/TA_1 & $\begin{array}{c}-0.498 \\
\left(-22.40^{* * *}\right)\end{array}$ & $\begin{array}{c}-0.176 \\
\left(-5.17^{* * *}\right)\end{array}$ \\
\hline NI/TA_1 & $\begin{array}{c}0.156 \\
\left(15.27^{* * *}\right)\end{array}$ & $\begin{array}{c}0.210 \\
\left(14.29^{* * *}\right)\end{array}$ \\
\hline CSR Score & $\begin{array}{l}-0.074 \\
(-1.68 *)\end{array}$ & $\begin{array}{l}-0.127 \\
\left(-2.00^{* *}\right)\end{array}$ \\
\hline SOE & $\begin{array}{c}-0.0005 \\
(-0.02)\end{array}$ & $\begin{array}{l}-0.134 \\
(-1.03)\end{array}$ \\
\hline InstSH & $\begin{array}{c}0.006 \\
\left(5.73^{* * *}\right)\end{array}$ & $\begin{array}{c}0.006 \\
\left(4.12^{* * *}\right)\end{array}$ \\
\hline InstSH * CSR Score & $\begin{array}{c}0.013 \\
\left(1.66^{*}\right)\end{array}$ & $\begin{array}{c}0.024 \\
\left(2.17^{* *}\right)\end{array}$ \\
\hline BS & $\begin{array}{l}-0.012 \\
\left(-2.40^{* *}\right)\end{array}$ & $\begin{array}{l}-0.016 \\
(-1.52)\end{array}$ \\
\hline Size & $\begin{array}{c}-0.041 \\
\left(-3.67^{* * *}\right)\end{array}$ & $\begin{array}{c}-0.294 \\
\left(-5.81^{* * *}\right)\end{array}$ \\
\hline No. of Observations & 1441 & 1441 \\
\hline $\mathrm{R}^{2}$ & 0.6125 & 0.4037 \\
\hline Model Test Stat & 1543.31 & 75.52 \\
\hline Prob & 0.0000 & 0.0000 \\
\hline $\begin{array}{c}\text { Hausman Chi-Sq (p-value) } \\
\text { Hansen Chi-Sq (p-value) }\end{array}$ & & $239.31(0.000)$ \\
\hline
\end{tabular}

Note: ${ }^{* * *}$, and ${ }^{* * *}$ are the level of significance at $10 \%, 5 \%$, and $1 \%$.

\subsection{Robustness Testing: Matched-pairs Sample}

To control for the potential characteristics of companies that may be associated with both the decision to disclose CSR information and the firm's market value, we also used a matched-sample design. For each DCSR firm-year, we identified a NDCSR firm-year based on the following characteristics: (1) the NDCSR matched company was from the same year as the DCSR firm, (2) the NDCSR matched firm was in the same industry as the DCSR firm, (3) the NDCSR matched company was within $\pm 25 \%$ of the DCSR firm size. Based on these criteria, we were unable to obtain matches for 296 DCSR companies.

The results of testing the firm value model on the matched sample are presented in Table 9. The results of our testing using the matched-sample design are in accord with the results of the non-matched sample. The results show that firm value is higher for firms that chose to disclose more CSR information in the presence of institutional investors. 
Table 9. Panel regression—market value to total asset—matched sample.

\begin{tabular}{|c|c|c|}
\hline Items & Random Effect & Fixed Effect \\
\hline Constant & $\begin{array}{c}0.143 \\
\left(3.60^{* * *}\right)\end{array}$ & $\begin{array}{c}5.60 \\
\left(10.96^{* * *}\right)\end{array}$ \\
\hline BV/TA_1 & $\begin{array}{c}-0.359 \\
\left(-24.81^{* * *}\right)\end{array}$ & $\begin{array}{c}-0.146 \\
\left(-7.78^{* * *}\right)\end{array}$ \\
\hline NI/TA_1 & $\begin{array}{l}0.006 \\
(0.95)\end{array}$ & $\begin{array}{c}0.026 \\
\left(2.87^{* *}\right)\end{array}$ \\
\hline Score & $\begin{array}{l}-0.001 \\
(-0.80)\end{array}$ & $\begin{array}{l}-0.007 \\
(-1.94 *)\end{array}$ \\
\hline SOE & $\begin{array}{c}0.098 \\
\left(5.73^{* * *}\right)\end{array}$ & $\begin{array}{l}0.071 \\
(0.97)\end{array}$ \\
\hline InstSH & $\begin{array}{c}0.005 \\
\left(6.75^{* * *}\right)\end{array}$ & $\begin{array}{l}0.002 \\
(1.60)\end{array}$ \\
\hline InstSH * Score & $\begin{array}{c}0.0006 \\
\left(4.00^{* * *}\right)\end{array}$ & $\begin{array}{c}0.0007 \\
\left(3.73^{* * *}\right)\end{array}$ \\
\hline BS & $\begin{array}{l}-0.0008 \\
(-0.34)\end{array}$ & $\begin{array}{l}-0.0008 \\
(-0.29)\end{array}$ \\
\hline Size & $\begin{array}{c}0.153 \\
\left(-19.84^{* * *}\right)\end{array}$ & $\begin{array}{c}-0.235 \\
\left(-10.51^{* * *}\right)\end{array}$ \\
\hline No. of Observations & 2757 & 2757 \\
\hline $\mathrm{R}^{2}$ & 0.4819 & 0.3460 \\
\hline Model Test Stat & 1573.37 & 33.01 \\
\hline Prob & 0.00 & 0.00 \\
\hline Hausman Chi-sq (p-value) & & $377.77(0.000)$ \\
\hline
\end{tabular}

Note: ${ }^{* * *}$, and ${ }^{* * *}$ are the level of significance at $10 \%, 5 \%$, and $1 \%$.

\section{Implications and Conclusions}

We examined the prevalence of CSR disclosures in China and the potential relationship between CSR information disclosure and the market value of the Chinese listed firms. We have chosen China to investigate value relevance of CSR due to the transition of China from a closed economy to a relatively open economy. This choice of the Chinese context permits us to contribute towards the notion of context-dependence of CSR, particularly in the context of a developing economy (Jamali and Karam, 2018 [29]; Windsor, 2019 [41]). The awareness and activities of CSR are in a more formative stage in China than the developed economies (Wang et al. 2016 [62]; Ali et al. 2017 [63]). We examined the value relevance of CSR disclosures of Chinese firms from 2008 (when CSR disclosure began to be encouraged) to 2012. During this time period, there has been a material increase in CSR disclosure; the numbers of firms who make CSR disclosures has been doubled over the period 2008-2012. There has been only the increase in the number of firms that make CSR disclosures and the CSR-disclosing firms have provided more information about their CSR. The main aspects of CSR disclosure are related to the protection of environment, employees, and shareholders. These findings regarding the types of CSR resonate with the survey by KPMG that has recognized China as one of the leading economies of the Asia-Pacific region for CSR disclosure (KPMG, 2013) [88].

In this study, we have found that there is a negative relationship between firm value and CSR disclosure. Our finding is consistent with the following studies which have found a negative association between CSR disclosure and market value of the firm (Wood and Jones 1995 [21]; Paine 2002 [22]; Barnett and Salomon, 2012 [24]; Al-Dah 2018 [40]). Furthermore, these results are also consistent with [54] argument that higher level of CSR disclosure may be exploited by the external stakeholders to reduce the value of firm. Ye and Zhang (2011) [66] also suggest that firm value may decline at very high levels of disclosure. Moreover, we have examined the relevance of an important boundary condition, i.e., interaction between CSR disclosure and institutional shareholding in the context of China. The inclusion of such a context-specific phenomenon is consistent with the recent debate about 
the context-dependency of CSR. Furthermore, it is argued by Matten and Moon (2008) [42], Jamali and Mirshak (2007) [43], Sajjad and Eweje (2014) [44], and Jamali and Karam (2018) [29] that there is a dearth of research regarding CSR in the context of developing economies. We filled these important gaps through this study. In this regard, our finding about the link between market value and interaction of CSR disclosure with institutional shareholding demonstrates that firms with higher institutional shareholding exhibit a positive link between market value and CSR. Hence, this important finding demonstrates that CSR disclosure is value relevant in those firms of a developing country in which institutional investors hold substantial ownership stakes.

The Ohlson model suggests that firms disclose information because disclosure can reduce information asymmetry between agents (managers) and principals (shareholders), and this model was the basis for our analyses. The reduction in the agency problem can enable investors to make appropriate assessments of cash flows and earnings, and can thereby increase the market value of those firms who make CSR disclosures to reduce information asymmetry. We extend the research on value relevance of CSR disclosures by considering the moderating role of institutional investors. We found a positive and significant relationship between the interaction of CSR disclosure and institutional shareholding and market value of the firm. This finding implies that CSR disclosure may be used more by institutional investors than the non-institutional investors (i.e., CSR disclosures are more value relevant to institutional investors). These findings are important for China, because the prevalence and role of institutional investors has evolved in China during recent times (Jiang and Kim 2015) [48]. Most of these institutional investors are foreign investors and these foreign investors may encourage more CSR activities in China (Lin 2010) [78].

In summary, our results indicate that shareholders reward firms for disclosing CSR information and this type of disclosure has higher value relevance. Furthermore, the value relevance of CSR disclosure is greater for institutional investors than for non-institutional investors. These findings are consistent with the notion that institutional investors are giving more importance to CSR disclosure from emerging economies like China. For the managers, our results imply that Chinese firms can benefit from conducting CSR activities due to the high value relevance of CSR disclosure.

This research has conducted an analysis of the value relevance of CSR disclosure from 2008 to 2012. Future studies can extend these time periods to capture the historic trends of CSR disclosure in China. Furthermore, this study has only examined the relevance of institutional investors, but future studies can include other types of investors and measure their preferences for different aspects of CSR disclosure. Future research may conduct a comparative analysis among developed and developing economies for better insights regarding the value relevance of CSR disclosure. For now, these results imply the value relevance of CSR disclosure in the context of the Chinese economy and especially the value relevance of CSR disclosure is more in those firms who have higher levels of institutional shareholding.

Author Contributions: R.u.R. as a lead author, contributed in the manuscript in several ways. Such as, conceptualization, data curation, formal analysis, investigation, methodology, and software handling. Z.R., the second author contributed in the conceptualization, formal analysis, validation, review writing and editing. C.C. contributed in the manuscript in following ways, original writing, project administration and resources. J.Z. contributed in the manuscript as supervisor and provided resources. F.W. contributed in revision and editing. All authors have read and agreed to the published version of the manuscript.

Funding: This study was supported by the Natural Science Foundation of China (Grant No. 71472148).

Acknowledgments: Authors would like to thank Tahreem Zia from the Lahore School of Economics for her assistance with the data analysis.

Conflicts of Interest: There is no conflict of interest between authors.

\section{References}

1. Cormier, D.; Ledoux, M.; Magnan, M. The informational contribution of social and environmental disclosures for investors. Manag. Decis. 2011, 49, 1276-1304. [CrossRef] 
2. Dhaliwal, D.S.; Li, O.Z.; Tsang, A.H.; Yang, Y.G. Voluntary non-financial disclosure and the cost of equity capital: The initiation of corporate social responsibility reporting. Account. Rev. 2011, 86, 59-100. [CrossRef]

3. Margolis, J.D.; Walsh, J.P. Misery Loves Companies: Rethinking Social Initiatives by Business. Adm. Sci. Q. 2003, 48, 268-305. [CrossRef]

4. Cho, S.Y.; Lee, C.; Pfeiffer, R.J., Jr. Corporate social responsibility performance and information asymmetry. J. Account. Public Policy 2013, 32, 71-83. [CrossRef]

5. De Klerk, M.; De Villiers, C.; Van Staden, C. The influence of corporate social responsibility disclosure on share prices: Evidence from the United Kingdom. Pac. Account. Rev. 2015, 27, 208-228. [CrossRef]

6. American Institute of Certified Public Accountants (AICPA). Improving Business Reporting-A Customer Focus; AICPA: New York, NY, USA, 1994.

7. Reverte, C. The impact of better corporate social responsibility disclosure on the cost of equity capital. Corp. Soc. Responsib. Environ. Manag. 2012, 19, 253-272. [CrossRef]

8. Wang, M.; Chen, Y. Does voluntary corporate social performance attract institutional investment? Evidence from China. Corp. Gov. 2017, 25, 338-357. [CrossRef]

9. Pun, N. The Moral Economy of Capital: Transnational Corporate Codes of Conduct and Labour Rights in China. In Proceedings of the Chinese University Conference: Chinese Trade Unions and the Labour Movement in the Market Economy, Hong Kong, China, 23-25 October 2003.

10. Zhou, W.D. Will CSR Work in China? Leading Perspectives, CSR in the People's Republic of China, Summer 2006; BSR: Shenzhen, China, 2006.

11. State-owned Asset Supervision and Administration Commission (SASAC). Guidelines to the State-owned Enterprises Directly under the Central Government on Fulfilling Corporate Social Responsibilities; SASAC: Beijing, China, 2011. Available online: http://en.sasac.gov.cn/n1408035/c1477196/content.html (accessed on 11 June 2011).

12. KPMG. Corporate Responsibility Reporting Survey 2017; KPMG: Amstelveen, The Netherlands, 2017.

13. Cochran, P.L.; Wood, R.A. Corporate social responsibility and financial performance. Acad. Manag. J. 1984, $27,42-56$.

14. Orlitzky, M.; Schmidt, F.; Rynes, S. Corporate social and financial performance: A metaanalysis. Organ. Stud. 2003, 24, 403-441. [CrossRef]

15. Allouche, J.; Laroche, P. A Meta-Analytical Investigation of the Relationship between Corporate Social and Financial Performance. Rev. De Gest. Des Ressour. Hum. 2005, 57, 8-41.

16. De Bakker, F.G.A.; Groenewegen, P.; Den Hond, F. A Bibliometric Analysis of 30 Years of Research and Theory on Corporate Social Responsibility and Corporate Social Performance. Bus. Soc. 2005, 44, 283-317. [CrossRef]

17. Wu, M. Corporate Social Performance, Corporate Financial Performance, and Firm Size: A Meta Analysis. J. Am. Acad. Bus. 2006, 8, 163-171.

18. Nakao, Y.; Amano, A.; Matsumura, K.; Genba, K.; Nakano, M. Relationship between environmental performance and financial performance: An empirical analysis of Japanese corporations. Bus. Strategy Environ. 2007, 16, 106-118. [CrossRef]

19. Clarkson, P.M.; Li, Y.; Richardson, G.; Vasvari, F.P. Does it really pay to be green? Determinants and consequences of proactive environmental strategies. J. Account. Public Policy 2011, 30, 122-144. [CrossRef]

20. Guenster, N.; Bauer, R.; Derwall, J.; Koedijk, K. The Economic Value of Corporate Eco-Efficiency. Eur. Financ. Manag. 2011, 17, 679-704. [CrossRef]

21. Wood, D.J.; Jones, R.E. Stakeholder mismatching: A theoretical problem in empirical research on corporate social performance. Int. J. Organ. Anal. 1995, 3, 229-267. [CrossRef]

22. Paine, L.S. Value Shift; McGraw-Hill: New York, NY, USA, 2002.

23. Iwata, H.; Okada, K. How does environmental performance affect financial performance? Evidence from Japanese manufacturing firms. Ecol. Econ. 2011, 70, 1691-1700. [CrossRef]

24. Barnett, M.L.; Salomon, R.M. Does it pay to be really good? Addressing the shape of the relationship between social and financial performance. Strateg. Manag. J. 2012, 33, 1304-1320. [CrossRef]

25. Chen, Y.C.; Hung, M.; Wang, Y. The effect of mandatory CSR disclosure on firm profitability and social externalities: Evidence from China. J. Account. Econ. 2018, 65, 169-190. [CrossRef] 
26. Gray, R.; Javad, M.; Power, D.M.; Sinclair, C.D. Social and Environmental Disclosure and corKPMG. 2011. KPMG International Survey of Corporate Responsibility Reporting. Available online: http://www.kpmg.com/Global/en/IssuesAndInsights/ArticlesPublications/corporate-responsibility/ Documents/2011-survey.pdf (accessed on 20 November 2012).

27. De Klerk, M.; De Villiers, C. The value relevance of corporate responsibility reporting: South African evidence. Meditari Account. Res. 2012, 20, 21-38. [CrossRef]

28. Isaksson, L.E.; Woodside, A.G. Modeling firm heterogeneity in corporate social performance and financial performance. J. Bus. Res. 2016, 69, 3285-3314. [CrossRef]

29. Jamali, D.; Karam, C. Corporate social responsibility in developing countries as an emerging field of study. Int. J. Manag. Rev. 2018, 20, 32-61. [CrossRef]

30. Basu, K.; Palazzo, G. Corporate social responsibility: A process model of sensemaking. Acad. Manag. Rev. 2008, 33, 122-136. [CrossRef]

31. Williams, S.M.; Pei, C.H.W. Corporate social disclosures by listed companies on their web sites: An international comparison. Int. J. Account. 1999, 34, 389-419. [CrossRef]

32. Smith, J.L.; Adhikari, A.; Tondkar, R.H. Exploring differences in social disclosures internationally: A stakeholder perspective. J. Account. Public Policy 2005, 24, 123-151. [CrossRef]

33. Gray, R.; Bebbington, J. Corporate sustainability, accountability and the pursuit of the impossible dream. In Handbook of Sustainable Development; Atkinson, G.S., Dietz, S., Neumeyer, E., Eds.; Edward Elgar: Cheltenham, UK, 2007; pp. 376-394.

34. Haniffa, R.M.; Cooke, T.E. The impact of culture and governance on corporate social reporting. J. Account. Public Policy 2005, 24, 391-430. [CrossRef]

35. Islam, M.A.; Deegan, C. Motivations for an organisation within a developing country to report social responsibility information: Evidence from Bangladesh, Accounting. Audit. Account. J. 2008, 21, 850-874. [CrossRef]

36. Baron, R.A.; Tang, J. Entrepreneurs' social skills and new venture performance: Mediating mechanisms and cultural generality. J. Manag. 2009, 35, 282-306. [CrossRef]

37. Du, X.; Du, Y.; Zeng, Q.; Pei, H.; Chang, Y. Religious atmosphere, law enforcement, and corporate social responsibility: Evidence from China. Asia Pac. J. Manag. 2016, 33, 229-265. [CrossRef]

38. Marquis, C.; Qian, C. Corporate social responsibility reporting in China: Symbol or substance? Organ. Sci. 2013, 25, 127-148. [CrossRef]

39. Singh, P.J.; Sethuraman, K.; Lam, J.Y. Impact of corporate social responsibility dimensions on firm value: Some evidence from Hong Kong and China. Sustainability 2017, 9, 1532. [CrossRef]

40. Al-Dah, B. Director interlocks and the strategic pacing of CSR activities. Manag. Decis. 2018, 57, $2782-2798$. [CrossRef]

41. Windsor, D. Defining corporate social responsibility for developing and developed countries: Comparing proposed approaches. In Corporate Social Responsibility: Concepts, Methodologies, Tools, and Applications; IGI Global: Hershey, PA, USA, 2019; pp. 1-27.

42. Matten, D.; Moon, J. "Implicit" and "explicit" CSR: A conceptual framework for a comparative understanding of corporate social responsibility. Acad. Manag. Rev. 2008, 33, 404-424. [CrossRef]

43. Jamali, D.; Mirshak, R. Corporate social responsibility (CSR): Theory and practice in a developing country context. J. Bus. Ethics 2007, 72, 243-262. [CrossRef]

44. Sajjad, A.; Eweje, G. Corporate Social Responsibility in Pakistan: Current Trends and Future Directions', Corporate Social Responsibility and Sustainability: Emerging Trends in Developing Economies (Critical Studies on Corporate Responsibility, Governance and Sustainability, Volume 8). In Emerging Trends in Developing Economies; Emerald Publishing: Bingley, UK, 2014; pp. 163-187.

45. De Villiers, C.; Marques, A. Corporate social responsibility, country-level predispositions, and the consequences of choosing a level of disclosure. Account. Bus. Res. 2016, 46, 167-195. [CrossRef]

46. Murray, A.; Sinclair, D.; Power, D.; Gray, R. Do financial markets care about social and environmental disclosure? Further evidence and exploration from the UK Accounting. Audit. Account. J. 2006, 19, $228-255$. [CrossRef]

47. Schadewitz, H.; Niskala, M. Communication via responsibility reporting and its effect on firm value in Finland. Corp. Soc. Responsib. Environ. Manag. 2010, 17, 96-106. [CrossRef] 
48. Jiang, F.; Kim, K.A. Corporate governance in China: A modern perspective. J. Corp. Financ. 2015, 32, $190-216$. [CrossRef]

49. Beaver, W. Financial Reporting: An Accounting Revolution, 3rd ed.; Prentice Hall: Upper Saddle River, NJ, USA, 1998.

50. Diamond, D.W.; Verrecchia, R.E. Disclosure, liquidity, and the cost of capital. J. Financ. 1991, 46, $1325-1359$. [CrossRef]

51. Gilson, R.J.; Kraakman, R.H. The mechanisms of market efficiency. Va. Law Rev. 1984, 70, 549-644. [CrossRef]

52. Merton, R.C. A simple model of capital market equilibrium with incomplete information. J. Financ. 1987, 42, 483-510. [CrossRef]

53. Thévenoz, L.; Bahar, R. Conflicts of interest: Disclosure, incentives and the market. In Conflicts of Interest: Corporate Governance and Financial Markets; Thévenoz, L., Bahar, R., Eds.; Kluwer Law International: Alphen aan den Rijn, The Netherland, 2007; pp. 1-29.

54. Healy, P.; Palepu, K.G. Information asymmetry, corporate disclosure, and capital markets: A review of empirical disclosure literature. J. Account. Econ. 2001, 31, 405-440. [CrossRef]

55. Cooper, K.; Keim, G.D. The economic rationale for the nature and extent of corporate financial disclosure regulation: A critical assessment. J. Account. Public Policy 1983, 2, 189-205. [CrossRef]

56. Eisenhardt, K.M. Agency theory: An assessment and review. Acad. Manag. Rev. 1989, 14, 57-74. [CrossRef]

57. Jain, T.; Aguilera, R.V.; Jamali, D. Corporate stakeholder orientation in an emerging country context: A longitudinal cross industry analysis. J. Bus. Ethics 2017, 143, 701-719. [CrossRef]

58. Qian, W.; Schaltegger, S. Revisiting carbon disclosure and performance: Legitimacy and management views. Br. Account. Rev. 2017, 49, 365-379. [CrossRef]

59. Shabana, K.M.; Buchholtz, A.K.; Carroll, A.B. The institutionalization of corporate social responsibility reporting. Bus. Soc. 2017, 56, 1107-1135. [CrossRef]

60. Lorraine, N.H.J.; Collison, D.J.; Power, D.M. An analysis of the stock market impact of environmental performance information. Account. Forum 2004, 28, 7-26. [CrossRef]

61. Curran, M.M.; Moran, D. Impact of the FTSE4Good Index on firm price: An event study. J. Environ. Manag. 2007, 82, 529-537. [CrossRef]

62. Wang, Q.; Dou, J.; Jia, S. A meta-analytic review of corporate social responsibility and corporate financial performance: The moderating effect of contextual factors. Bus. Soc. 2016, 55, 1083-1121. [CrossRef]

63. Ali, W.; Frynas, J.G.; Mahmood, Z. Determinants of corporate social responsibility (CSR) disclosure in developed and developing countries: A literature review. Corp. Soc. Responsib. Environ. Manag. 2017, 24, 273-294. [CrossRef]

64. Cheng, S.; Lin, K.Z.; Wong, W. Corporate social responsibility reporting and firm performance: Evidence from China. J. Manag. Gov. 2016, 20, 503-523. [CrossRef]

65. Li, Q.; Luo, W.; Wang, Y.; Wu, L. Firm performance, corporate ownership, and corporate social responsibility disclosure in China. Bus. Ethics 2013, 22, 159-173. [CrossRef]

66. Ye, K.; Zhang, R. Do lenders value corporate social responsibility? Evidence from China. J. Bus. Ethics 2011, 104, 197-206. [CrossRef]

67. Cho, C.H.; Michelon, G.; Patten, D.M.; Roberts, R.W. CSR disclosure: The more things change? Accounting. Audit. Account. J. 2015, 28, 14-35. [CrossRef]

68. Cahan, S.F.; De Villiers, D.; Jeter, D.C.; Naikers, V.; Van Staden, C.J. Are CSR Disclosures Value Relevant? Cross-Country Evidence. Eur. Account. Rev. 2016, 25, 579-611. [CrossRef]

69. Plumlee, M.; Brown, D.; Hayes, R.M.; Marshall, R.S. Voluntary environmental disclosure quality and firm value: Further evidence. J. Account. Public Policy 2015, 34, 336-361. [CrossRef]

70. Peloza, J.; Falkenberg, L. The role of collaboration in achieving corporate social responsibility objectives. Calif. Manag. Rev. 2009, 51, 95-113. [CrossRef]

71. Waddock, S.A.; Graves, S.B. The corporate social performance-financial performance link. Strateg. Manag. J. 1997, 18, 303-319. [CrossRef]

72. McGuire, J.B.; Schneeweis, T.; Branch, B. Perceptions of firm quality: A cause or result of firm performance. J. Manag. 1990, 16, 167-180. [CrossRef]

73. Godfrey, P.C.; Merrill, C.B.; Hansen, J.M. The relationship between corporate social responsibility and shareholder value: An empirical test of the risk management hypothesis. Strateg. Manag. J. 2009, 30, 425-445. [CrossRef] 
74. Julian, S.D.; Ofori-dankwa, J.C. Financial resource availability and corporate social responsibility expenditures in a sub-Saharan economy: The institutional difference hypothesis. Strateg. Manag. J. 2013, 34, 1314-1330. [CrossRef]

75. Solomon, J.F.; Solomon, A. Private social, ethical and environmental disclosure. Account. Audit. Account. J. 2006, 19, 564-591. [CrossRef]

76. Solomon, J.A.; Solomon, S. Norton: Socially Responsible Investment in the UK: Drivers and Current Issues. J. Gen. Manag. 2002, 27, 1-13.

77. De Villiers, C.; Van Staden, C.J. Shareholders' requirements for corporate environmental disclosures: A cross country comparison. Br. Account. Rev. 2010, 42, 227-240. [CrossRef]

78. Lin, L.W. Corporate social responsibility in China: Window dressing or structural change? Berkeley J. Int. Law 2010, 28, 64-100.

79. Firth, M.; Gao, J.; Shen, J.; Zhang, Y. Institutional stock ownership and firms' cash dividend policies: Evidence from China. J. Bank. Financ. 2016, 65, 91-107. [CrossRef]

80. Peng, F.; Kang, L.; Jiang, J. Selection and institutional shareholder activism in Chinese acquisitions. Manag. Decis. 2013, 51, 141-162. [CrossRef]

81. Holder-Webb, L.; Cohen, J.R.; Nath, L.; Wood, D. The supply of corporate social responsibility disclosures among US firms. J. Bus. Ethics 2009, 84, 497-527. [CrossRef]

82. Ohlson, J.A. Earnings, book values and dividends in security valuation. Contemp. Account. Res. 1995, 11, 661-687. [CrossRef]

83. Gujarati, D.N. Basic Econometrics; Tata McGraw-Hill Education: Gautam Budh Nagar Noida, India, 2009.

84. Tabachnick, B.G.; Fidell, L.S. Using multivariate statistics: International edition; Pearson: Melbourne, Australia, 2012.

85. Cavaco, S.; Crifo, P. CSR and financial performance: Complementarity between environmental, social and business behaviours. Appl. Econ. 2014, 46, 3323-3338. [CrossRef]

86. Belu, C.; Manescu, C. Strategic corporate social responsibility and economic performance. Appl. Econ. 2013, 45, 2751-2764. [CrossRef]

87. Hansen, L.P. Large sample properties of generalized method of moments estimators. Econometrica 1982, 50, 1029-1054. [CrossRef]

88. KPMG. Corporate Responsibility Reporting Survey 2013; KPMG: Amstelveen, The Netherlands, 2013. 